\section{From Mild to Severe Primary Hyperparathyroidism: The Brazilian Experience}

\begin{abstract}
Primary hyperparathyroidism often presents as an asymptomatic disorder. In our institution, routine serum calcium measurements have now been used as part of medical examination for 23 years. Out of 124 patients consecutively seen at our institution, $47 \%$ presented with no symptoms related to the disease, while $25 \%$ presented with severe skeletal involvement and osteitis fibrosa cystica, $25 \%$ with renal stone disease without overt bone involvement, and $2 \%$ with the typical neuropsychiatric syndrome. This same pattern is seen in the city of São Paulo. In severe disease pathological fractures are frequently seen, especially in long bones of the lower extremities, and also loss of lamina dura of the teeth and salt-and-pepper appearance of the skull. Bone mineral density is extremely low in these patients but usually show remarkable recovery following surgical cure. Serum PTH and bone markers are considerable higher in severely affected patients, who also have a high rate of vitamin D deficiency, and the parathyroid lesion is easier located compared with asymptomatic patients. From pathological specimens $87 \%$ had histological confirmation of a single adenoma, $6.4 \%$ multiple gland hyperplasia and $3.8 \%$ carcinoma. (Arq Bras Endocrinol Metab 2006;50/4:657-663)
\end{abstract}

Keywords: Primary hyperparathyroidism; Osteoporosis; Bone markers; Bone density; Vitamin D

\section{RESUMO}

Do Hiperparatiroidismo Primário Leve ao Severo: A Experiência Brasileira. Na maioria dos relatos da literatura recente, o hiperparatiroidismo primário apresenta-se, com freqüência, na forma assintomática. Em nossa instituição utilizamos a determinação rotineira do cálcio sérico há 23 anos. Em nossa série de 124 casos consecutivos, $45 \%$ não apresentavam sintomas relacionados com a doença, $25 \%$ tinham envolvimento esquelético intenso com osteíte fibrosa cística, $25 \%$ tinham nefrolitíase sem envolvimento ósseo severo, e 2\% apresentavam a síndrome neuro-psiquiátrica típica. Esse mesmo padrão tem sido observado na cidade de São Paulo. Na doença severa são freqüentes as fraturas patológicas, especialmente nos ossos longos dos membros inferiores, como também a reabsorção da lâmina dura dos dentes e o aspecto em "sal e pimenta" nas radiografias do crânio. A densidade mineral óssea mostra-se extremamente reduzida nesses pacientes, mas em geral exibe melhora marcante após a cura cirúrgica. O PTH no soro e os marcadores bioquímicos da remodelação óssea estão significativamente mais altos nos pacientes com doença severa, os quais freqüentemente apresentam deficiência de vitamina $D$ e localização mais fácil da lesão paratiroideana, quando comparados aos pacientes assintomáticos. Ao exame anátomo-patológico, 87\% tiveram confirmação de adenoma único, 6,4\% hiperplasia glandular difusa e 3,8\% carcinoma. (Arq Bras Endocrinol Metab 2006;50/4:657-663)

Descritores: Hiperparatiroidismo; Osteoporose; Marcadores ósseos; Densidade óssea; Vitamina D

\section{original article}

\author{
Francisco Bandeira \\ Luiz Griz \\ Gustavo Caldas \\ Cristina Bandeira \\ Eduardo Freese
}

Department of Medicine, Division of Endocrinology, Agamenon Magalhães Hospital, University of Pernambuco (FB, $L G, G C$ \& $C B$ ); and Department of Public Health and Epidemiology, Aggeu Magalhães Research Center, Oswaldo Cruz Foundation, Ministry of Health (EF), Recife, PE, Brazil. 
$\mathbf{I}^{\mathrm{N}}$ MOST SERIES PRIMARY hyperparathyroidism typically presents as an asymptomatic disorder, which has been, for the most part, attributable to the introduction of routine screening started in the mid 1970s (1-3). In our institution, routine serum calcium measurements have now been used as part of medical examination for 23 years (4). Out of 124 patients consecutively seen at our institution, $47 \%$ presented with no symptoms related to the disease, while $25 \%$ presented with severe skeletal involvement and osteitis fibrosa cystica (table 1), 25\% with renal stone disease without overt bone involvement, and $2 \%$ with the typical neuropsychiatric syndrome. Six patients were discovered by means of high serum PTH and persistent normal serum calcium levels without thiazide diuretic use or vitamin D deficiency and were considered as having normocalcemic primary hyperparathyroidism. In the UK and USA, for example, it presents in $0.1-1 \%$ considering population and institutional data. In Europe recent data show a prevalence of $2-3 \%$ in postmenopausal women. The incidence is 30-150 cases per 100.000 population/year (5). At our institution, including outpatients and inpatients, the prevalence in postmenopausal women is $1.3 \%$.

\section{CLINICAL PRESENTATION}

Although a few patients present with neuropsychiatric effects of hypercalcemia such as anxiety, depression, and confusion, one quarter of our patients exhibit signs and symptoms referable to bone involvement. Bone pain, pathological fractures and muscle weakness are the most common features, and the bone tumors can be palpated, especially along the shafts of the long bone of the extremities, in most patients (figure 1). Muscle weakness is frequently proximal and usually manifested with hyperactive deep tendon reflexes. Renal disease almost always presents with episodes of renal colic with evidence of solitary calculi, and few patients show fea- tures of nephrocalcinosis and renal insufficiency. In approximately $65 \%$ of the patients with osteitis fibrosa cystica there is no evidence of renal stone disease.

\section{RADIOGRAPHS}

Intense demineralization is observed on bone $\mathrm{X}$-rays in patients with severe disease. A pathological fracture is frequently seen, especially in long bones of the lower extremities, and also loss of lamina dura of the teeth and salt-and-pepper appearance of the skull (figure 2). Subperiosteal bone erosions in the distal phalanges and over the lateral borders of the medial phalanges are also usually seen as numerous lytic lesions with irregular and sclerotic margins, which are more common in the pelvis, long bones and shoulders. The cortical of the long bones is extremely thin, and in some patients, almost absent (figure 3 ).

\section{BONE MINERAL DENSITY}

From the original 124 patient-cohort, 91 had bone mineral density measured: 51 asymptomatic, 23 with renal stone without overt bone disease, 16 with osteitis fibrosa cystica, and 1 with the neuropsychiatric syndrome. In asymptomatic patients the mean $\mathrm{t}$-score BMD was $-2.4 \pm 0.6$ at the lumbar spine, $-1.5 \pm 0.7$ at the femoral neck, and $-1.8 \pm 0.6$ at the distal radius, and in renal stone disease patients without overt bone disease it is $-2.4 \pm 0.5,-2.0 \pm 0.8$, and $-1.7 \pm 0.7$ respectively. In patients with osteitis fibrosa cystica the mean $\mathrm{t}$-score $\mathrm{BMD}$ at the lumbar spine is $\mathbf{- 5 . 2 \pm 0 . 5}$ $(\mathrm{p}<0.01$ vs. asymptomatic patients $),-6.2 \pm 0.8$ at the femoral neck $(\mathrm{p}=0.002)$, and $-5.8 \pm 0.5$ at the distal radius $(\mathrm{p}=0.002)$.

Changes in BMD following surgical cure in patients with severe disease are usually remarkable. During the first year median changes were as follows: 100\%

Table 1. Characteristics of patients with hypercalcemic primary hyperparathyroidism according to clinical presentation.

\begin{tabular}{lccc} 
& $\begin{array}{c}\text { Asymptomatic } \\
\mathbf{n = 5 9}\end{array}$ & $\begin{array}{c}\text { Osteitis fibrosa cystica } \\
\mathbf{n = 3 1}\end{array}$ & \\
\hline Age (years) & $68.6 \pm 17.3$ & $40.2 \pm 18.1$ & $\mathrm{p}<0.01$ \\
Gender & $6 \mathrm{M} 53 \mathrm{~F}$ & $10 \mathrm{M} 21 \mathrm{~F}$ & \\
Serum calcium (mg/dl) & $10.9 \pm 0.4$ & $14.0 \pm 0.7$ & $\mathrm{p}<0.001$ \\
Serum phosphorus (mg/dl) & $2.96 \pm 0.2$ & $2.0 \pm 0.5$ & $\mathrm{p}<0.01$ \\
Serum PTH (pg/ml) & $133 \pm 29$ & $1820 \pm 349$ & $\mathrm{p}<0.0001$ \\
\hline
\end{tabular}

sPTH: serum parathyroid hormone sCalcium: serum calcium

sPhophorus: serum phophorus
OF: osteitis fibrosa cystica

RS: renal stone disease

NPS: neuropsychiatric syndrome 


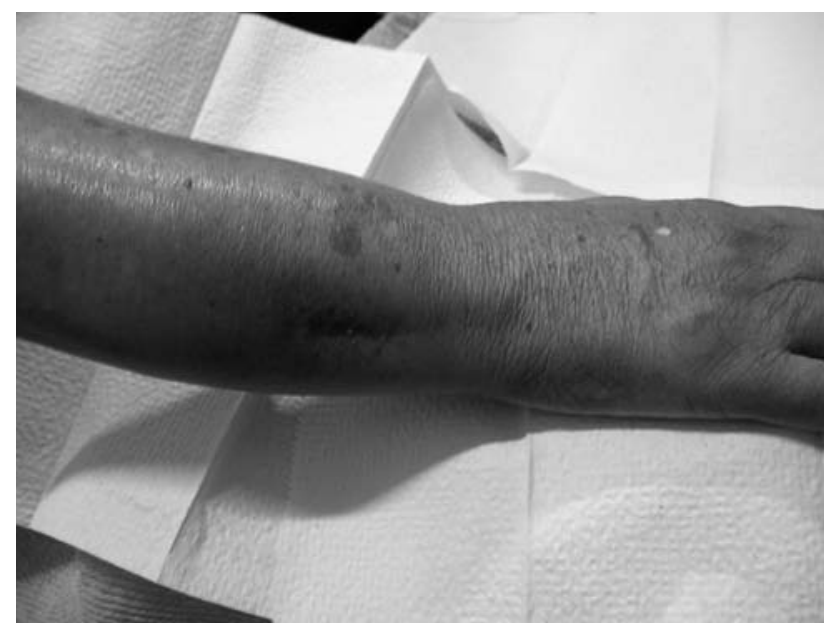

Figure 1. A 48-year-old woman with osteitis fibrosa cystica showing a visible tumor at the right distal radius.

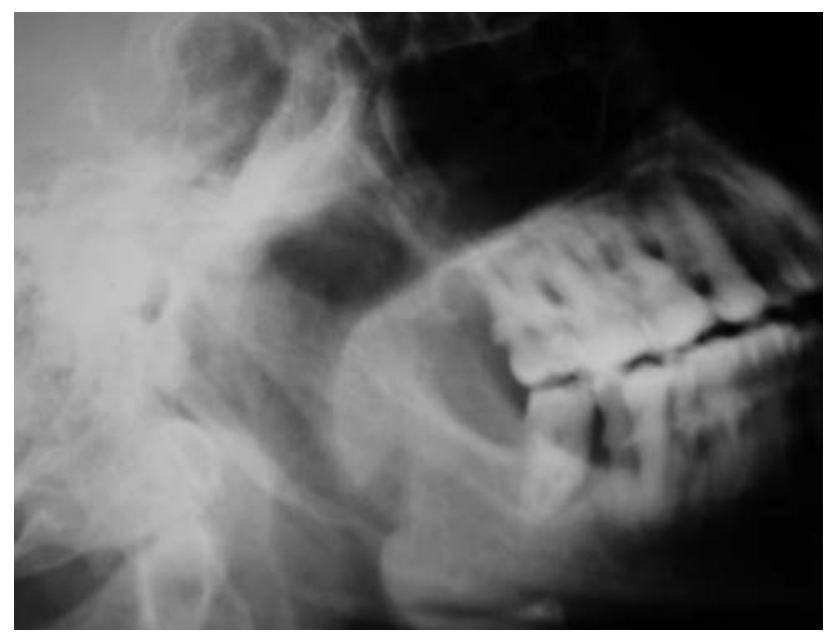

Figure 2. Loss of lamina dura of the upper teeth in osteitis fibrosa cystica.
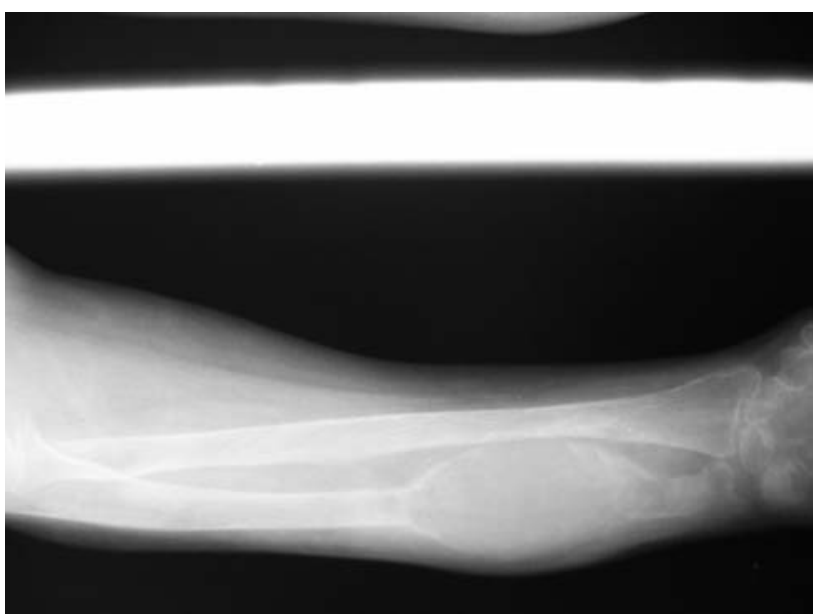

Figure 3. Arm $\mathrm{X}$-rays of the same patient as figure 2, exhibiting thin cortices and a brown tumor.

at the lumbar spine, $144 \%$ at the femoral neck, and $27 \%$ at distal radius (6). On the other hand patients with asymptomatic disease show a mean increment in BMD of 2.9 to $10 \%$ at the lumbar spine and 4.1 to $8 \%$ at the femoral neck in 5 years $(7,8)$. Although the precise mechanisms of recovery in bone mass in these patients are not fully understood, it is likely that the postoperative changes in bone density represent a true anabolic effect as serum PTH is elevated in the presence of hypocalcemia during a prolonged period after parathyroidectomy, reflecting the "hungry bones" in which the patients usually require relatively high doses of calcium and vitamin D supplementations (9).

In postmenopausal women with asymptomatic primary hyperparathyroidism, cortical geometry is sig- nificantly affected in comparison with controls (10) and in patients in whom bone specimens were evaluated by bone histomorphometry, it showed significantly higher values, compared with controls, for the wall width of trabecular bone packets, the adjusted apposition rate, and the active formation period, which are consistent with a stimulatory action of elevated PTH levels on the duration of the active bone formation phase in the individuals' remodeling units, and may account for some preservation in cancellous bone in postmenopausal women (11).

Also, the differences in the mode of presentation regarding involvement in severe bone disease may well reflect the very high levels of PTH usually seen in patients with osteitis fibrosa cystica. 


\section{LABORATORY DATA}

Patients with severe primary hyperparathyroidism have higher mean levels of serum calcium and lower levels of serum phosphorus concentration compared with asymptomatic individuals $(14.0 \pm 0.7$ vs. $10.9 \pm 0.4$ $\mathrm{mg} / \mathrm{dl}, \mathrm{p}<0.00 \mathrm{l} ;$ and $2.0 \pm 0.5$ vs. $2.96 \pm 0.2 \mathrm{mg} / \mathrm{dl}$, $\mathrm{p}<0.01$, respectively). More pronounced are the differences in intact PTH serum levels: $1820 \pm 349$ vs. $133 \pm 29 \mathrm{pg} / \mathrm{ml}, \mathrm{p}<0.001$. Urinary calcium excretion is increased in about $40 \%$ of patients with OF, in $50 \%$ of patients with renal stone disease, and in $30 \%$ of asymptomatic patients (12).

Although considerably younger than the asymptomatic group, patients with osteitis fibrosa cystica have significantly lower mean 25-OHD levels (16.7 vs. $29.9 \mathrm{ng} / \mathrm{ml}$ ), as do patients with renal stone disease $(20.6 \mathrm{ng} / \mathrm{ml})$.

Using a cut-off point of $25 \mathrm{ng} / \mathrm{ml}$, we found that $29 \%$ of patient with asymptomatic disease were vitamin $\mathrm{D}$ deficient, in comparison with $70 \%$ of patients with renal stone disease. All patients with $\mathrm{OF}$ had serum 25-OHD levels of less than $25 \mathrm{ng} / \mathrm{ml}$.

In fact in the US, vitamin D deficiency is present in about $28 \%$ of patients with asymptomatic primary hyperparathyroidism, and these patients tend to have higher serum PTH and alkaline phosphatase levels compared with the non-vitamin $\mathrm{D}$ deficient patients (13).

In India and China, where primary hyperparathyroidism is manifested almost exclusively as severe disease, vitamin $\mathrm{D}$ deficiency remains endemic, with mean 25-OHD levels of 8.7 and $8.8 \mathrm{ng} / \mathrm{ml}$, respectively, in two studies. Also several studies during the past few years, including our own, have found occult vitamin $\mathrm{D}$ deficiency or insufficiency in sunny countries in the Mediterranean region and areas of the Middle East, as well as in Brazil (14-16).

In patients with osteitis fibrosa cystica, severe hypocalcemia due to hungry bone syndrome develops in nearly all patients, and after normalization of serum PTH on the first postoperative day, they usually require a high dose of vitamin D and calcium supplements to avoid hypocalcemia which lasts for several months after surgical cure. In patients with $\mathrm{OF}$, severe hypocalcemia due to hungry bone syndrome can be prevented by a short preoperative course of a potent bisphosphonate (17).

Alkaline phosphatase is high in all patients with osteitis fibrosa cystica, with mean values 10 times the upper limit of normal, and mildly elevated in about $30 \%$ of patients with nephrolithiasis with no evidence of osteitis fibrosa cystica.
Mean urinary N-telopeptide and serum b-Ctelopeptide levels are significantly higher in patients with osteitis fibrosa cystica $(501.5 \pm 201.7$ vs. $51.3 \pm$ $6.4 \mathrm{nmol} / \mathrm{mmolCr}, \mathrm{p}<0.05$; and $2516.8 \pm 822.7$ vs. $729.9 \pm 407.8 \mathrm{pg} / \mathrm{ml}, \mathrm{p}=0.002$, respectively). These markers, as well as alkaline phosphatase, usually show a marked fall after parathyroidectomy and tend to normalize as the patients become vitamin D sufficient with the use of vitamin D and calcium supplements.

In postmenopausal women with asymptomatic primary hyperparathyroidism maximum postparathyroidectomy changes in urinary markers such as deoxypyridinoline and $\mathrm{N}$-telopeptide tend to occur at day 1 , and correspond to $-21 \%$ and $-33 \%$ respectively. The changes in bone formation markers tend to occur 5 to 12 days later (18).

\section{LOCALIZATION PROCEDURES AND TREATMENT}

The use of Tc99m-sestamibi scanning in the preoperative localization of parathyroid lesions has improved the success rate of surgery, especially in patients who have undergone previous neck surgery (19). Using the traditional surgical operation, patients with a positive scan may have a higher cure rate than patients with a negative scan. On the other hand a positive scan may provide the opportunity to perform the minimally invasive approach (MIP).

From our cohort we evaluated the accuracy of this technique in 64 patients according to the clinical manifestation of the disease (20). The sestamibi scan was positive in $64 \%$ of asymptomatic patients, $83 \%$ of patients with renal stone without overt bone disease, and in $100 \%$ of patients with osteitis fibrosa cystica. Of those patients with severe bone disease, $70 \%$ already showed an increased uptake in the initial images (10-15 minutes), compared with asymptomatic patients, in whom the increase in uptake was seen only in the later images, as expected (figure 4). When minimally invasive parathyroidectomy is the preferred operation, intraoperative $\mathrm{PTH}$ testing (IOPTH) is also available (2l) to guide the surgeon regarding the removal of an abnormal parathyroid gland $(50 \%$ fall from preoperative values, ten minutes after surgical excision of the parathyroid tumor). Both sestamibi scanning and IOPTH are less accurate in patients with multiple gland disease $(35-50 \%)$.

Out of 78 operations in our cohort, $87 \%$ had histological confirmation of a single adenoma, $6.4 \%$ multiple gland hyperplasia and $3.8 \%$ carcinoma (table 2 ). In 
the city of São Paulo, Ohe et al. (22) have observed a change in the clinical presentation of PHPT in a cohort of 104 patients from 1985 to 2002 , as more asymptomatic cases had been detected with the use of routine serum calcium measurement. This led to an expected decline in the rate of parathyroidectomy (table 3).

In patients with osteitis fibrosa cystica sestamibi may be taken up by bony lesions, and this leads one to suspect parathyroid cancer with bone metastasis. However Tc-99 sestamibi can also be taken up by skeletal brown tumors, mimicking metastatic parathyroid cancer. This may be due to increased perfusion, metabolism, and osteoclastic activity (23).

On April 8-9, 2002, a Workshop on Asymptomatic Primary Hyperparathyroidism was held at the National Institutes of Health (24), at which the former recommendations from the 1990 NIH Consensus Conference were changed as follows: 1 - Serum calcium 1 $\mathrm{mg} / \mathrm{dl}$ above upper limit of normal; 2 - Twenty fourhour urinary calcium excretion above $400 \mathrm{mg}$; 3 - Crea- tinine clearance reduced by $30 \% ; 4-\mathrm{t}$-score Bone mineral density below -2.5 at any site; 5 - Age below 50 years. Patients with symptomatic primary hyperparathyroidism, in whom known target organ complications such as severe bone disease, fractures, renal stones, and overt neuromuscular dysfunction, are present, should always be strongly advised to undergo parathyroidectomy.

\section{CONCLUSIONS}

Many aspects distinguish mild from severe primary hyperparathyroidism and the occurrence of these more aggressive forms may well be due to factors other than the lack of serum calcium screening. Vitamin D deficiency is a common factor that may have a major influence on the clinical course of the disease. Bone mineral density is extremely low, and bone turnover extremely high, in patients with severe disease but, in most cases, reversible after surgical cure.
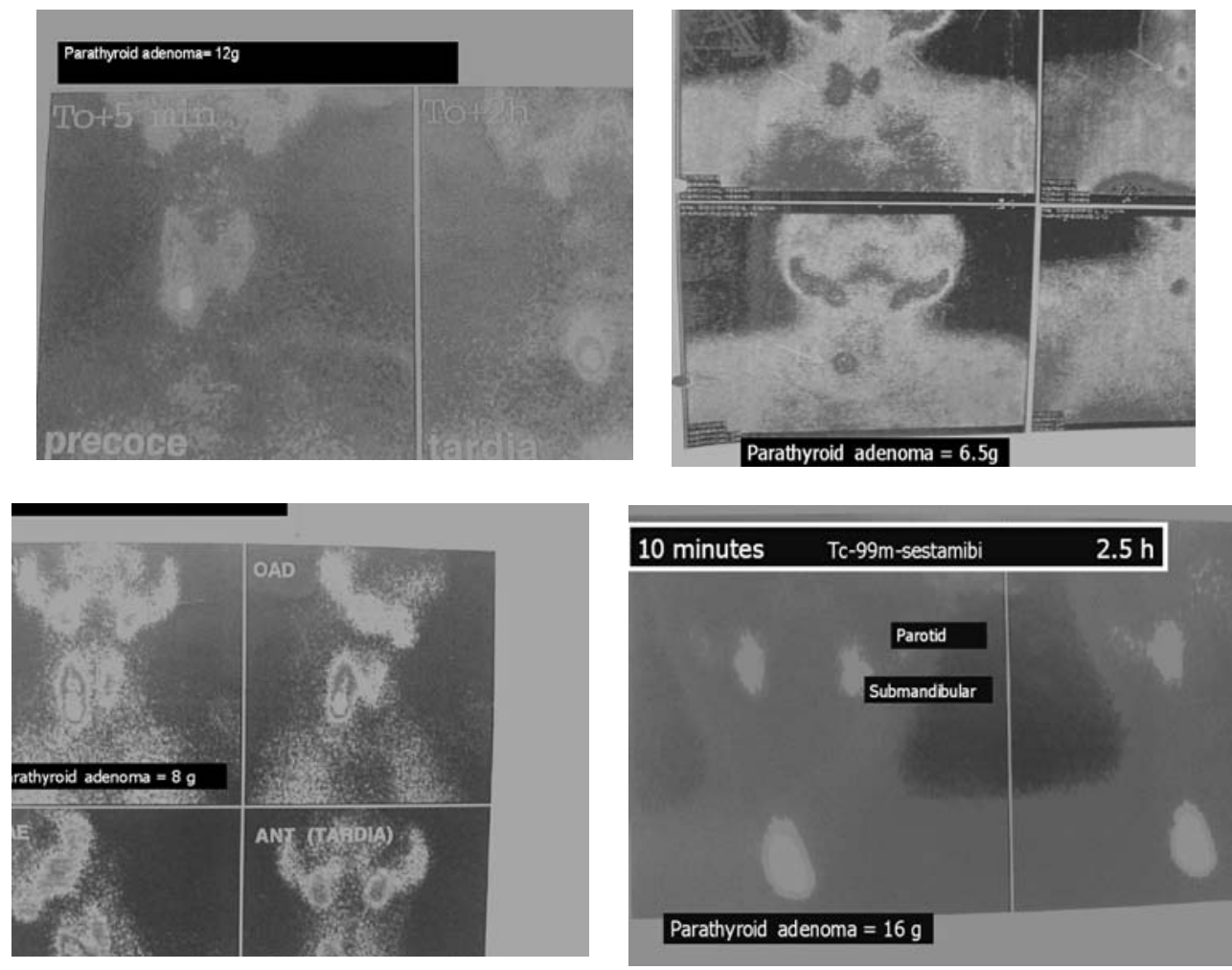

Figure 4. Neck cintigraphy showing large parathyroid masses in 4 patients with severe primary hyperparathyroidism. Note the characteristic early uptake of Tc-99-sestamibi. 
Table 2. Pathologic findings in surgical specimens from 78 patients with primary hyperparathyroidism.

\begin{tabular}{ll}
\hline OF (31 patients, 1 MEN 2A) & 25 single adenomas (89.2\%) \\
28 operations & 3 carcinomas (10.7\%) \\
\hline RS (31 patients) & 27 single adenomas (90\%) \\
30 operations (1 MEN 1) & 2 hyperplasia (7\%) \\
& 1 unsuccessful \\
\hline As (59 patients) & 14 single adenomas (82.3\%) \\
17 operations & 1 multiple adenoma \\
& 2 hyperplasia \\
\hline NPS (3 patients) & 2 single adenomas \\
3 operations & 1 hyperplasia \\
\hline
\end{tabular}

Table 3. Change in the pattern of clinical presentation and the rate of parathyroidectomy in the city of São Paulo. Data from Federal University of Sao Paulo (UNIFESP).

\begin{tabular}{lccccc}
\hline Period & $\mathbf{n}$ & Mean age $(\mathbf{y r})$ & \% AS & Mean serum calcium & \% operated \\
\hline $1985-1991$ & 13 & $46.9 \pm 15$ & 8 & $13.4 \pm 1.48$ & 100 \\
$1992-1996$ & 40 & $59.3 \pm 14.2$ & 37 & $11.9 \pm 1.48$ & 87.5 \\
$1997-2001$ & 46 & $52.1 \pm 17$ & 50 & $11.7 \pm 1.2$ & 67 \\
\hline
\end{tabular}

AS denotes asymptomatic primary hyperparathyroidism

\section{REFERENCES}

1. Purnell DC, Smith LH, Scholz DA, Elveback LR, Arnaud CD. Primary hyperparathyroisism: a prospective clinical study. Am J Med 1971;50: 670-8.

2. Heath III H, Hodgson SF, Kennedy MA. Primary hyperparathyroidism: incidence, morbidity, and economic impact in a community. N Engl J Med 1980;302:189-93.

3. Mundy GR, Cove DH, Fisken R. Primary hyperparathyroidism: changes in the pattern of clinical presentation. Lancet 1980;1:1317-20.

4. Bandeira F, Griz L, Caldas $G$, Macedo G, Bandeira C. Characteristics of primary hyperparathyroidism in one Institution in Northeast Brazil. Bone 1998;5(suppl):S380.

5. Consensus Development Conference Panel. Diagnosis and management of asymptomatic primary hyperparathyroidism. Ann Intern Med 1991; 114:593-7.

6. Bandeira F, Griz L, Caldas G, Bandeira C. Characteristics of bone loss in primary hyperparathyroidism with severe osteitis fibrosa cystica - Effects of parathyroidectomy. Proc. of the 82nd Annual Meeting of The Endocrine Society 2000; Toronto. p. 421.

7. Silverberg S, Shane E, Jacobs T, Siris E, Bilezikian J. A 10year prospective study of primary hyperparathyroidism with or without parathyroid surgery. N Engl J Med 1999;341:1249-55

8. Hagstrom E, Lundgren E, Mallmin H, Rastad J, Rastad J, Hellman P. Positive effect of parathyroidectomy on bone mineral density in mild asymptomatic primary hyperparathyroidism. J Inter Med 2006;259:191-8.

9. Kulak C, Bandeira C, Voss D, Sobieszczyk S, Silverberg S, Bandeira $F$, et al. Marked improvement in bone mass after parathyroidectomy in osteitis fibrosa cystica. J Clin Endocrinol Metab 1998;83:732-5.

10. Charopoulos I, Tournis S, Trovas G, Raptou P, Kaldrymides $P$, Skarandavos $G$, et al. Effects of primary hyperparathyroidism on volumetric bone mineral density and bone geometry assessed by peripheral quantitative tomography in postmenopausal women. J Clin Endocrinol Metab 2006; 91(5): 1748-53.

11. Dempster D, Parisien M, Silverberg S, Liang X, Schnitzer $M$, Shen W, et al. On the mechanism of cancellous bone preservation in postmenopausal women with mild primary hyperparathyroidism. J Clin Endocrinol Metab 1999;84: 1562-6.

12. Bandeira F, Caldas $G$, Freese $E$, Griz L, Faria M, Bandeira C. Relationship between vitamin D serum status and clinical manifestations of primary hyperparathyroidism. Endocr Pract 2002;8:266-70.

13. Locker F, Parisien M, Dempster D, Bilezikian J. Vitamin D deficiency may alter the clinical course of primary hyperparathyroidism. J Bone Miner Res 1997;(Suppl) :S522.

14. Gannage-Yared MH, Chemali R, Yaacoub N, Halaby G. Hypovitaminosis $D$ in a sunny country: relation to lifestyle and bone markers. J Bone Miner Res 2000; 15:1856-62.

15. Rao D, Agarwal G, Talpos G, Phillips E, Bandeira F, Mishra $S$, et al. Role of vitamin $D$ and calcium nutrition in disease expression and parathyroid tumor growth in primary hyperparathyroidism: a global perspective. J Bone Miner Res 2002;17(suppl. 2):N75-N80.

16. Bilezikian JP, Meng X, Shi Y, Silverberg SJ. Primary hyperparathyroidism in women: a tale of two cities - New York and Beijing. Int J Fert Womens Med 2000;45:158-65.

17. Bandeira F, Griz L, Caldas G, Freese E, Macedo G, Bandeira $C$. Effects of preoperative use of bisphosphonates in primary hyperparathyroidism with severe osteitis fibrosa cystica. Proceedings of the $84^{\text {th }}$ Annual Meeting 
of The Endocrine Society 2002; San Francisco. p. 452.

18. Guo C, Holland P, Jackson B, Hannon R, Harrison H, Eastell R. Immediate changes in bone turnover after parathyroidectomy for primary hyperparathyroidism. J Bone Miner Res 1997;12:(suppl):S523.

19. Allendorf J, Kim L, Chabot J, LoGerfo P. The impact of sestamibi scanning on the outcome of parathyroid surgery. J Clin Endocrinol Metab 2003;88:3015-8.

20. Bandeira F, Coriolano A, Griz L, Caldas G, et al. Differences in accuracy of the Sestamibi scanning between severe and mild forms of primary hyperparathyroidism. J Bone Miner Res 2005;20 (suppl. 1):S298.

21. Ohe MN, Santos RO, Kunii IS, Carvalho AB, Abrahao M, Cervantes $O$, et al. Usefulness of a rapid immunometric assay for intraoperative parathyroid hormone measurements. Braz J Med Biol Res 2003;36:715-21.

22. Ohe MN, Santos RO, Barros ER, Lage ER, Kuniil IS, Abrahao $\mathrm{M}$, et al. Change in the clinical and laboratorial findings in primary hyperparathyroidism in a University Hospital in São Paulo from 1985-2002. Braz J Med Biol Res 2005;38:2-5.
23. Rubin M, LiVolsi $V$, Bandeira F, Caldas $G$, Bilezikian J. Tc$99 \mathrm{~m}$-Sestamibi uptake in osteitis fibrosa cystica simulating metastatic bone disease. J Clin Endocrinol Metab 2001;86:5138-41.

24. Bilezikian JP, Potts JT, El-Hajj Fuleihan G, Kleerekoper M, Neer $R$, Peacock $M$, et al. Summary statement from a Workshop on Asymptomatic Primary Hyperparathyroidism: A perspective for the $21^{\text {st }}$ century. J Bone Miner Res 2002; 17(suppl. 2):N2-N1 1 .

\section{Address for correspondence:}

Francisco Bandeira

Department of Medicine, University of Pernambuco

Division of Endocrinology, Agamenon Magalhães Hospital Dilab Laboratories

Rua da Hora 378/402

52020-010 Recife, PE, Brazil 